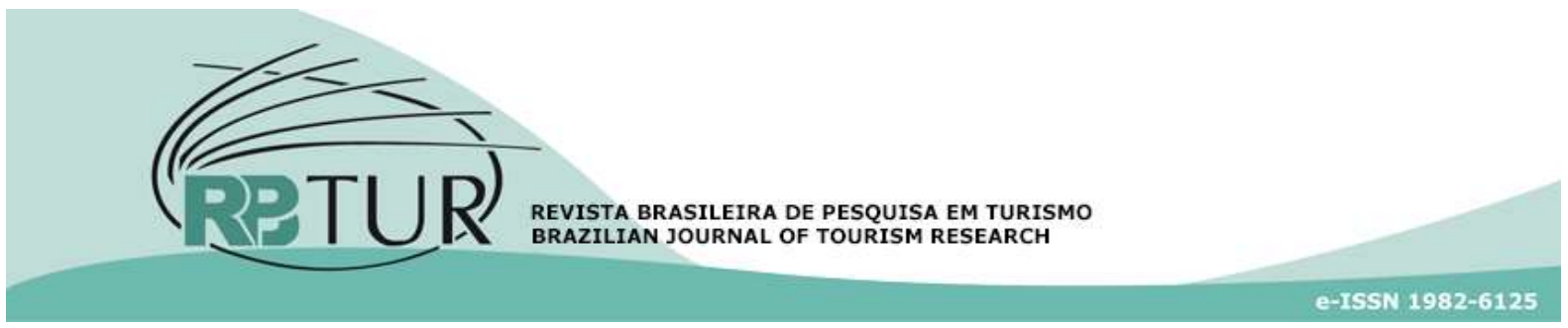

Paper

DOI: http://dx.doi.org/10.7784/rbtur.v12i2.1432

\title{
The convergence of environmental sustainability and ocean cruises in two moments: in the academic research and corporate communication
}

\author{
A convergência da sustentabilidade ambiental com os cruzeiros \\ marítimos em dois momentos: na pesquisa acadêmica e na \\ comunicação das empresas do setor
}

\section{La convergencia de la sostenibilidad ambiental con los cruceros marítimos en dos momentos: en la investigación académica y en la comunicación de las empresas del sector}

\author{
Carlos Eduardo de Almeida Ramoa ${ }^{1}$ \\ Luiz Carlos da Silva Flores ${ }^{2}$ \\ Bernd Stecker ${ }^{3}$
}

\begin{abstract}
Concerns for world peace, freedom, and the future of people and the planet have led to several United Nations Conferences, generating discussions on global sustainable development. These efforts resulted in the 2030 Agenda and its 17 Sustainable Development Goals (SDGs). The proposed Goal 14 reflects the concern for the conservation and sustainable use of oceans, seas, and marine resources. In this context, the research objects of this study are ocean cruise ships and the main dimension surveyed is environmental sustainability. Firstly, the study sought to identify through the convergence of the dimensions of sustainability and cruises the contributions to the cruise industry that promote the SDGs. To this end, we carried out a bibliometric analysis of scientific production on cruise ship environment, narrowing the research focus on environmentally sustainable practices.

\footnotetext{
${ }^{1}$ University of Vale do Itajaí (UNIVALI), Balneário Camboriú, SC, Brasil. Department: Research Group for Hotel Management and Tourism. Conception and research design, formulation of ideas, state of art research, data analysis, critical review and final approval.

${ }^{2}$ University of Vale do Itajai (UNIVALI). Balneário Camboriú, SC, Brasil. Department: Research Group for Hotel Management and Tourism Services at University of Vale do Itajaí, Brazil (UNIVALI). Critical review and final approval.

${ }^{3}$ City University of Applied Sciences, Hochschule Bremen, Faculty of Social Sciences, Department: Sustainability in Leisure \& Tourism, Bremen, Germany. Critical review and final approval.
}

Paper received in: 05/03/2018. Paper accepted in: 28/05/2018. 
Ramoa, C. E. A. ; Silva Flores, L. C.; Stecker, B. The convergence of environmental sustainability and ocean cruises in two moments: in the academic research and corporate communication

The second research objective is to examine cruise companies' strategic inclination to provide information on environmental initiatives to the market. The results show little scientific research focused on the convergence of the two topics studied, environmental sustainability and cruises. Only 12 scientific articles were identified. Regarding the information on environmentally sustainable practices, the findings show that only $22.6 \%$ of the 31 cruise companies surveyed provide this information on their corporate websites.

Keywords: Sustainable development. Sustainability. Environmental sustainability. Cruise industry. Cruise ship. Strategy.

Resumo: A preocupação com a paz universal, com a liberdade, com o futuro das pessoas e do planeta tem sido motivo para a realização de diversas Conferências organizadas pela ONU, o que tem gerado debates visando o desenvolvimento globalmente sustentável. Esses esforços resultaram na elaboração da Agenda 2030 e seus 17 Objetivos para os Objetivos de Desenvolvimento Sustentável (ODS), sendo que um deles, o objetivo 14, reflete a preocupação com a conservação e o uso sustentável dos oceanos, mares e recursos marinhos e é nesse contexto que esta pesquisa é apresentada, tendo os navios de cruzeiros marítimos como objeto de estudo e a sustentabilidade ambiental como a principal dimensão pesquisada. Em um primeiro momento, o estudo procurou identificar, através da convergência das dimensões sustentabilidade ambiental e cruzeiros, as contribuições para o setor de cruzeiros que promovam os ODS. Para este fim, realizou-se uma análise bibliométrica da produção científica no ambiente dos navios de cruzeiros, restringindo-se o foco da pesquisa às práticas ambientalmente sustentáveis. Como segundo objetivo, a pesquisa expõe a predisposição estratégica das companhias marítimas em divulgar suas iniciativas ambientais ao mercado. A pesquisa identificou a baixa produção científica com ênfase na convergência dos dois temas pesquisados, obtendo-se apenas 12 artigos científicos publicados até agosto de 2017. Relativo à divulgação das práticas ambientalmente sustentáveis, verificou-se que apenas $22,6 \%$ das 31 companhias de cruzeiros pesquisadas, divulgam essas informações em seus websites corporativos.

Palavras-chave: Desenvolvimento sustentável. Sustentabilidade. Sustentabilidade ambiental. Cruzeiros marítimos. Estratégia.

Resumen: La preocupación por la paz universal, con la libertad, con el futuro de las personas y del planeta ha sido motivo para la realización de diversas Conferencias organizadas por la ONU, lo que ha generado debates para el desarrollo globalmente sostenible. Estos esfuerzos resultaron en la elaboración de la Agenda 2030 y sus 17 Objetivos para los Objetivos de Desarrollo Sostenible (ODS), uno de ellos, el objetivo 14, refleja la preocupación por la conservación y el uso sostenible de los océanos, mares y recursos marinos y es en ese contexto que esta investigación es presentada, teniendo los barcos de cruceros marítimos como objeto de estudio y la sustentabilidad ambiental como la principal dimensión investigada. En un primer momento, el estudio buscó identificar, a través de la convergencia de las dimensiones sustentabilidad ambiental y cruceros, las contribuciones para el sector de cruceros que promuevan los ODS. Para este fin, se realizó un análisis bibliométrico de la producción científica en el ambiente de los barcos de cruceros, restringiendo el foco de la investigación a las prácticas ambientalmente sustentables. Como segundo objetivo, la investigación expone la predisposición estratégica de las compañías marítimas en divulgar sus iniciativas ambientales al mercado. La investigación identificó la baja producción científica con énfasis en la convergencia de los dos temas investigados, obteniéndose sólo 12 artículos científicos publicados hasta agosto de 2017. En cuanto a la divulgación de las prácticas ambientalmente sostenibles, se verificó que sólo el $22,6 \%$ los cruceros encuestados, divulgan esa información en sus sitios web corporativos.

Palabras clave: Desarrollo sostenible. Sostenibilidad, Sostenibilidad del medio ambiente. Cruceros marítimos, Estrategia.

\section{INTRODUCTION}

Sustainable development has been a topic of discussion in several sectors of the economy, in the most diverse activities, including tourism (Doran \& Larsen, 2014; 
Marzo-Navarro, Pedraja-Iglesias, \& Vinzón, 2015; Roe, Hrymak, \& Dimanche, 2014; Rosalind Jenkins \& Karanikola, 2014; Whitfield, Dioko, \& Webber, 2014), for its contribution to maintaining the planet's environmental balance, social sustainability, and the economic development of destinations (Kuščer, 2013; Marzo-Navarro et al., 2015; Rodrigues, Rodrigues, \& Peroff, 2015; Suntikul \& Dorji, 2016).

However, despite the sustainable potential, tourism is responsible for a high amount of irreversible environmental damages. For example, the tourism industry uses polluting transport systems and promotes real estate developments that damage natural environments in addition to other activities that threaten biodiversity (Gopal, 2014; UNWTO, 2015; Vezzani, 2008).

The cruise industry is a fast-growing sector that contributes to these impacts. It represents around $2 \%$ of the global tourism in number of travelers (Brida, Chiappa, Meleddu, \& Pulina, 2012), with 23 million passengers/year sailing on more than 300 cruise ships, contributing with US\$ 117 billion to the world's economy (CLIA, 2016a, 2016b), developing tourism and several sectors of the economy (Jones, Comfort, \& Hillier, 2016; Strazza, Del Borghi, Gallo, Manariti, \& Missanelli, 2015), such as the naval industry, transportation, lodging or food and beverages, generating employment and contributing to the development of destinations (CLIA, 2016a; CLIA Europe, 2015; FGV, 2016).

Despite their significant role in the economic development of the marine destinations, cruise ships, increasingly larger, carrying more passengers, with infrastructure similar to that of a tourist destination (Gibson, 2012; Lohmann \& Panosso-Netto, 2012; Mancini, 2011; Najafipour, Marzi, \& Foroozanfar, 2014) are potentially polluting environments (Friends of Earth, 2016; Hall, Wood, \& Wilson, 2017; Klein, 2009, 2010, 2011; Lindgren, Wilewska-Bien, Granhag, Andersson, \& Eriksson, 2016; Stefanidaki \& Lekakou, 2014) like any other tourism activity (Buckley, 2012; Gopal, 2014; Pires, 2012; UNWTO, 2015).

Organizations are becoming more proactive in their engagement with sustainable practices, due to environmental concerns, but also because of the growing environmental awareness of consumers (Chiu, Lee, \& Chen, 2013; Lin, 2017; Pires, 2012; Tiago, Faria, Cogumbreiro, Couto, \& Tiago, 2016).

Therefore, adopting environmentally sustainable practices can be considered a strategic differentiator, an asset in winning this new consumer, environmentally aware and seeking a better quality of life. This influences the choice of environmentally friendly products and services (Adams, Font, \& Stanford, 2017; Ardoin, Wheaton, Bowers, Hunt, \& Durham, 2015; Crespo, 2015; Jäckel, Fodor, \& Papp, 2015; Stecker, 2016; Wakita \& Oishi, 2016).

Considering the importance of the environmentally sustainable development of the marine environment (United Nations, 2015a), this study sought to identify the scientific convergence between the dimensions of environmental sustainability and ocean cruise ships. To that end, this exploratory and descriptive study, with an inductive method and a qualitative approach, presents a biblio- 
metric analysis of scientific production on ocean cruise ships environmental sustainability.

Moreover, the adoption of best practices and the environmental impacts that need to be managed (Rosa \& Silva, 2017) by shipping companies are also issues addressed in this study. In this context, the research delves into the strategic attitude of shipping companies regarding environmental responsibility, reflected in communications to target markets in their corporate websites.

The two objectives of this study, one academic and the other market oriented, are related. On one hand, the analysis on scientific production identified the requirements and best environmental practices; on the other hand, the study examined the level of transparency of cruise companies regarding information on environmental requirements and indicators, and how it affects the choice of a tourism product.

This study is part of a research project whose aim is to create a strategic management model based on the adoption of the best environmental practices by cruise ships, through the management of environmental requirements and their indicators. The research was carried out between July and August 2017, using literature review methodology to conduct a bibliometric study of scientific production indexed in the Scopus database.

\section{METHODOLOGY}

The various United Nations conferences on sustainable development since Rio 1992 (United Nations, 1992, 1998, 2000,
2002, 2005, 2010, 2012b, 2012a, 2016b), have inspired organizations such as the Foundation for Environmental Education (FEE), Global Reporting Initiative (GRI), Global Sustainable Tourism Council (GSTC), International Maritime Organization (IMO), International Organization for Standardization (ISO), United Nations Environment Program (UNEP), World Tourism Organization (UNWTO), World Travel \& Tourism Council (WTTC), among others, which play a key role in raising awareness of sustainability issues among governments and, consequently, of public and private organizations.

Sustainability management in organizations has brought benefits to society. This dimension has gained importance in the risk management of cruise tourism and the industry reports on the subject have become useful tools for improving corporate image, a complex topic for tourism destinations, according to Santos \& Silva (2015), in a highly competitive market (Bonilla-Priego, Font, \& Pacheco-Olivares, 2014; Jones, Comfort, et al., 2016; Klein, 2011; Walker \& Moscardo, 2014).

Therefore, from the various sources of technical and scientific information it is important, in the formulation of strategy, to determine the best practices in sustainability that organizations should adopt. According to Mintzberg et al. (2007) companies must implement decision-making strategies towards development and sustainable growth. This means that, in line with Schaltegger, Lüdeke-Freund and Hansen's (2016) perspective, sustainability will not be achieved unless organizations adopt sustainable development as a business model, as a key strategic 
factor.

To meet the proposed objectives, this article included two analytical steps, since cruise companies do not prioritize environmental issues in their strategies (Friends of Earth, 2016; Hall et al., 2017; Jones, Comfort, et al., 2016; Jones, Hillier, \& Comfort, 2016; Klein, 2009). Thus, the study assumes that knowing the requirements of environmental sustainability helps shipping companies to understand the environment where they operate and is an indispensable tool to take on economic, social, and environmental challenges and the relationships between them.

In this context, this exploratory and descriptive research, using the inductive method and a qualitative approach, presents a bibliometric analysis to meet the objective: to analyze scientific publications on environmental sustainability in the context of ocean cruise ships. Thus, the main objective is to identify publications focusing on environmental requirements.

In order to identify studies and proposals on environmentally sustainable development in the cruise ship industry, two bibliometric studies were developed, using as main keywords 'cruises' and 'sustainability' and related terms. The research was carried out between June and July 2016, with direct access to EBSCO, Emerald, Ingenta Connect, SAGE, Scielo, Science Direct, Spell, Taylor \& Francis, Wiley, and Dart- Europe E-theses Portal. The reason for using these databases was the impossibility, at this stage of the research, of accessing the Scopus database in the place where the study was being conducted. Subsequently, the research was complemented with a second bibliometric study carried out between July and August 2017, in the Scopus database.

In addition to the bibliometric analysis, a qualitative research was carried out to verify if the shipping companies provide current and potential customers with information on environmental sustainability requirements and indicators evaluated (Godemann \& Michelsen, 2011; Herzig \& Schaltegger, 2011) on their cruise ships. To this end, we analyzed the websites of the 31 global cruise line members of Cruise Line International Association (CLIA, 2018).

The focus of this research is on marine environment, however we did not consider whether the companies provided river or sea cruises because, as we realized at this stage of the study, some of them operate in both environments. In addition, economic, sociocultural, or environmental sustainability principles should guide any organization, regardless of activity or sector (United Nations, 2007, 2012a, 2015c; WEF, 2014; World Bank, 2016).

Qualitative data were analyzed quantitatively, using descriptive statistics, seeking to draw conclusions from the qualitative research responses. The data were numerically evaluated by calculating frequencies, a technique commonly used in British leisure and tourism research (Veal, 2011), to explain the theories (Creswell \& Poth, 2016), allowing a flexible interpretation in the construction of the analysis (Sampieri, Collado, \& Lucio, 2013).

\section{SUSTAINABLE DEVELOPMENT}

In September 2015, in New York, Uni- 
ted States, Heads of State and Government met to formalize a new agenda for global development, the 2030 Agenda for Sustainable Development which includes 17 Sustainable Development Goals (SDGs) and 169 targets to be achieved over the next fifteen years, from 2015 (United Nations, 2015c). The Agenda is a plan of action for people, planet and prosperity and it "seeks to strengthen universal peace in larger freedom. We recognize that eradicating poverty in all its forms and dimensions, including extreme poverty, is the greatest global challenge and an indispensable requirement for sustainable development" (United Nations, 2015c, p. 1). Given the object of this study, the ocean cruises, the Goal 14 is of particular interest as it refers to "conserve and sustainably use the oceans, seas and marine resources for sustainable development", which thus relates to the environment of ocean cruises (United Nations, 2015c, p. 14).

In order to minimize the impacts caused by ships to the environment, it is imperative that cruise companies adopt sustainable development, which, according to the United Nations $(2009$, p. 78 ) is:

development that meets the needs of the present without compromising the ability of future generations to meet their own needs. It includes economic, environmental, and social sustainability, which can be achieved by rationally managing physical, natural and human capital.

However, Daly (1990) argues that organizations should seek sustainable development, not only sustainable growth, since development focuses on qualitative attributes, which aim to improve the quality of life, while growth, sustainable or not, focuses on a quantitative increase.

Therefore, meeting the needs of present and future generations depends on public awareness of environmental conservation, in this new global order of sustainable development (ICSU, 2017; United Nations, 2009, 2015c, 2016a, 2016c).

In addition to the United Nations guidelines and the spontaneous adoption of environmentally responsible principles by organizations, the new consumer can also influence companies to become more environmentally conscientious and act according to the principles of sustainable development; thus, these companies, trying to survive, will have to meet the three dimensions known as the Triple Bottom Line (TBL) for the Sustainable Development (Elkington, 2012; United Nations, 1987). TBL defines corporate sustainability and the benefits to the planet when the best sustainability practices are adopted by public and private businesses, offering organizations the path to sustainable development.

The concept of the tripod is based on the three pillars of sustainability, the 3 Ps: People, Planet and Profit. According to Elkington (2012), profit, the economic pillar, is the most comfortable pillar for companies, since they are profit-oriented

In adopting the concept, an organization to be financially viable and economically sustainable, needs to be socially equitable and environmentally responsible. The mentioned author (op. cit.) argues that the TBLbased agenda will not only bring economic 
return, but will also add to the organization's environmental and social value (Elkington, 2012; L. R. Oliveira, Medeiros, Terra, \& Quelhas, 2012).

Therefore, TBL should be part of the strategic scope of all organizations, including the accommodation establishments. Cruise ships, carrying guests from one destination to another (Dowling, 2006; Mendes \& Silva, 2012; OMT, 2008; Tarlow, 2012), are considered travelling hotels (Agarwal, 2002; Papatheodorou, 2004; Walton, 2009) comparable to competitors such as resorts (Dowling, 2006; Fonseca, 2012; V. A. dos Santos, 2009).

\subsection{Environmental sustainability in cruise ships}

There are several definitions of environmental sustainability ( $\mathrm{H}$. Daly \& Cobb, 1994; H. E. Daly, 1990; Goodland, 1995, 2002; Goodland \& Daly, 1996; Sachs, 1993, 2009; Sutton, 2004; United Nations, 2009; UNWTO, 2015; WEF, 2014); however, in general, they all converge on the same goal (Goodland, 1995) and principles defined by TBL (Elkington, 2012; United Nations, 2002). According to Goodland (2002), environmental sustainability, the focus of this research, originated from social concerns that converged on the need to maintain the natural capital, which is composed of water, land, air, minerals, and ecosystem services.

The United Nations (2009) consider the environmental sustainability as the longterm ability of natural and environmental resources and ecosystem services to support continued well-being. The final goal of these words and expressions is the same, i.e. the conservation of areas and natural resources and their ecosystems, through the control of environmental impacts. Briefly, the essence of the meaning of environmental sustainability can be "the maintenance of Natural Capital" (H. E. Daly, 1990, p. 1).

It should be noted that UNWTO $(2015$, p. 1) defines sustainable tourism "as tourism that takes full account of its current and future economic, social, and environmental impacts, addressing the needs of visitors, the industry, the environment, and host communities", furthermore the organization stresses that "achieving sustainable tourism is a continuous process and it requires constant monitoring of impacts, introducing the necessary preventive and/or corrective measures whenever necessary".

Likewise, the responsible use of the marine environment for tourism is not always an easy task for some countries, as is the case of Brazil (Brotto, Pimentel, Behrends, Alves, \& Moraes, 2016). Despite the Government's commitment and awareness (Brasil, 2017) few actions to raise awareness among residents and tourists, or inspections have been taken to date (W. A. Oliveira \& Da Silva, 2016; Pirajá, 2015). This can be due to the socio-economic situation of the country, one of the five most unequal in the world (Souza \& Medeiros, 2017).

This should not occur in a country that has more than $8,000 \mathrm{~km}$ of coastline (Khan et al., 2016), where coastal tourism and marine resources play an important role in the economy (Alves \& Hanazaki, 2015; Miranda, Santos, Gomes, Fernandez, \& Lourenção, 2015). In this respect, the main shipping com- 
panies operating in Brazil, the global companies Costa Cruises, MSC Cruises, NCL Cruise Line and Pullmantur (CLIA Brasil, 2018) share responsibility for adopting the best environmental practices, thus minimizing the impacts caused by their ships on the Brazilian coast.

Throughout history, oceans and seas have provided vital resources for the trade, transportation, and survival of mankind, contributing to poverty reduction, namely through small-scale fisheries, despite difficulties inherent to this activity (Alves \& Hanazaki, 2015; Sowman et al., 2014; UNWTO, 2016; Weeratunge et al., 2014). Therefore, the shipping companies and their cruise ships have responsibility for the marine environment and the conservation of the natural resources, since they operate in this environment, providing attractions for tourism and leisure activities.

According to Hall et al. (2017), despite the increasing involvement of the cruise industry in terms of sustainability, disclosing results is not a common practice among all companies, and there is no standard for the reports presented. In keeping with these findings, the study by Jones et al. (2016a) on transparency disclosure of sustainability indicators showed that among the leading companies, only the Carnival Corporation group, which includes Costa Cruises, the Holland America Line and Princess Cruises, and Royal Caribbean Cruises, also the owner of Azamara Club Cruises, publish detailed reports on aspects related to sustainability, including social, economic, and environmental issues. Besides these companies, according to the authors (op. cit.), some other shipping companies such as Norwegian Cruise Lines, MSC Cruises, Disney Cruises, Thomson Cruises, Star Cruises, and Silversea, release limited information on the subject.

It is important to note that the Carnival Corporation group has a market share of $47.4 \%$ and revenues of $39.4 \%$ and the Royal Caribbean International $23.0 \%$ and $20.2 \%$ market share and revenue respectively (Cruise Market Watch, 2018), totaling 71.2\% of the cruise market and $64.3 \%$ of global sales.

Although not all cruise lines release sustainability indicators, the global network Friends of the Earth, based in Washington DC, United States, is "working in solidarity for sustainable, equitable and just societies" in 75 countries (Friends of Earth, 2017). It has contributed to the discussion, namely through the Cruise Ship Report Card, which aims to disclose the impacts caused by the cruise ships, through a comparison of the environmental footprint (Wackernagel \& Rees, 1998) of four environmental requirements assessed on 17 cruise lines (Friends of Earth, 2016):

(1) Sewage treatment: Whether a cruise line has installed the most advanced sewage and wastewater treatment systems available instead of dumping minimally treated sewage directly into the water;

(2) Air pollution reduction: Whether a cruise line has retrofitted its ships to "plug in" to available shoreside electrical grids or installed scrubbers to reduce air pollution;

(3) Water Quality Compliance: To what degree cruise ships violated 2010- 
2014 water pollution standards designed to better protect the Alaskan coast.

(4) Transparency: Did the cruise lines respond to our requests for information regarding their environmental practices.

According to the FOE (Friends of Earth) report (Friends of Earth, 2016), in a scale from A to F, Disney Cruise Line is the most sustainable company on the market, with an average grade of $A$ - in the general context, being $A$ for sewage treatment, $C$ - in air pollution reduction, $A$ in water quality compliance and $A$ in transparency.

Regarding the ships, there are 15 vessels that have reached the average $A$ for the requirements presented, namely: Grand Princess, Island Princess, Regal Princess, Sea Princess, and Sun Princess; Jewel of the Seas (Royal Caribbean); Norwegian Breakaway, Norwegian Jewel, Radiance of the Seas and Serenade of the Seas (Norwegian Cruise Lines); Oosterdam, Veendam, Westerdam and Zuiderdam (Holland America Line), and Queen Mary II (Cunard Cruise Line) (Friends of Earth, 2016).

The fact that not all cruise companies release environmental indicators reports, leave them at the mercy of reports prepared and disseminated by third parties, which may also contain information useful to the market, since according to Klein (2009), a cruise ship is not the most environmentally sustainable means of transport. On average, carbon emissions of a cruise are three times higher than those of an airplane, train, or passenger ferry.

According to Gössling and Peeters
(2015) $\mathrm{CO}_{2}$ emissions per cruise trip per passenger are $1.2 \mathrm{t} \mathrm{CO}_{2}$ as an estimated global average and emissions per cruise passenger per day are $169 \mathrm{~kg} \mathrm{CO}_{2}$ as an estimated global average. In addition, it is estimated that a cruise ship carrying 2,200 passengers and 800 crew members, manages 210,000 gallons of human sewage, one million gallons of grey water, eight tons of garbage, more than 130 gallons of hazardous waste, and 25,000 gallons of oily bilge water.

The organization Nature and Biodiversity Conservation Union (NABU, 2017) states that ships are generally responsible for much of the air pollution in Europe, causing the premature death of about 50,000 people each year because of the black carbon, nitrogen oxide, and sulphur emissions of international shipping in European waters. The negative impacts can inspire environmentally sustainable initiatives of shipping companies, although two companies already release performance indicators for environmental aspects (Jones, Comfort, et al., 2016), Royal Caribbean (Royal Caribbean, 2017) and Costa Cruises (Costa Cruises, 2015).

Both companies have adopted the performance indicators defined by the Global Reporting Initiative (GRI, 2018, p. 1), an international non-governmental organization, based in Amsterdam, Netherlands, which conducts research to "understand and communicate the impact of business on critical sustainability issues such as climate change, human rights, corruption and many others." The reports presented by the two companies are based on the fourth-generation guidelines (G4) issued by GRI in 2013 (GRI, 2013), a set of variables of economic, environmental, 
Ramoa, C. E. A. ; Silva Flores, L. C.; Stecker, B. The convergence of environmental sustainability and ocean cruises in two moments: in the academic research and corporate communication

and social aspects of business performance.

It is important to note that the lack of information on environmental controls by cruise ships does not mean that cruise companies are not meeting international or national standards regarding environmental sustainability (Hall et al., 2017), however, the lack of knowledge on the subject may lead the environmentally-aware traveler to opt for transparent organizations, competitors (or not) of cruises, that are focused on sustainable development as a strategic pillar.

In this sense, it is imperative that shipbuilding companies adopt the best environmental practices as guiding principles (Fodness, 2016; United Nations, 2015b) regarding sustainable development of the marine environment, by integrating cleaner operations and monitoring the main requirements and environmental variables of this system, highlighting the following requirements and variables that were identified by Author (in press) in a survey that identifies the environmental factors that should be primarily managed in ocean cruise ships. This study adds to the requirements identified by Friends of the Earth (2016) environmental factors included in the International Maritime Association (IMO) and International Standard Association (ISO) guidelines, with the contribution of the analysis of the Scopus articles presented here, which confirm these requirements:

(1) Input management (consumption of environmentally sustainable products) (ABNT, 2014; ISO, 2016a);

(2) Waste management (black water, grey water, sewage sludge, solid waste, hazardous waste, oily bilge water, ballast water) (ABNT, 2014; Friends of Earth, 2016; IMO, 2016a, 2016b, 2016c, 2016e);

(3) Air quality (air pollution - gases and noises) (ABNT, 2014; IMO, 1980, 2016d);

(4) Energy management (energy efficiency) (ABNT, 2014; ISO, 2016b);

(5) Water management (water usage efficiency) (ABNT, 2014; ISO, 2014);

(6) Transparency (publication of environmental indicators) (Friends of Earth, 2016).

It is important to emphasize that these variables can also be interpreted as indicators of environmental sustainability (Bellen, 2007), however, in this study we called them, preferably, variables because at this moment there is no purpose in identifying or establishing numerical parameters (Cooper \& Schindler, 2003).

Therefore, from the establishment of requirements and variables, cruise companies, in order to integrate cleaner operations on their ships with the marine environment, should adopt indicators and respective parameters for sustainable practices; not only because of environmental awareness or strategic value, but also because of transparency with stakeholders regarding initiatives related to environmental responsibility, in particular to the communities along the way and in the destinations that suffer from direct impacts of cruise ships. In this way, the institutions and the market will know what is being done regarding the protection of the oceans, which could increase public awareness of marine environment. 


\section{RESULTS AND DISCUSSION}

The importance of the cruise industry for tourism is recognized (Coggins Jr, 2014; Hwang \& Han, 2014; Kerswill \& Mair, 2015; Klein, 2011; Panosso-Netto \& Trigo, 2009; Pavlić, 2013; C. E. de A. Ramoa \& Flores, 2015; Weeden, Lester, \& Thyne, 2011), however, this is not reflected in the number of scientific papers found in this research, which identified 925 journals indexed in the Scopus database mentioning this subject, which corresponds to only $0.5 \%$ of the number of publications related to the dimension of tourism.

Scientific production on tourism was analyzed in this first stage of the study, in a search in the Scopus database, between July 18 and August 14, 2017, seeking to identify publications encompassing the two dimensions: (1) cruises and (2) sustainability.

The keywords were selected considering the conceptual framework of the study, which addresses the importance of sustainable development and sustainability, particularly the environmental sustainability dimension and its interaction with the object of the study, the ocean cruise ships.

In order to meet the objective of analyzing the scientific production focusing on environmental sustainability in cruise ships, we first defined a set of keywords related to the dimension of cruises: "cruise" or "cruise ship" or "cruise industry" or "cruise tourism" or "maritime cruise" or "maritime tourism" or "nautical tourism" or "ocean cruising", obtaining 5,859 scientific papers that addressed the topic at some point in the research.

The dimension of "sustainability" was included in the Boolean search formula narrowing down the number of publications to 707. Then, a new filter was used, looking for convergence of strategic predisposition in tourism, area which includes the ocean cruises ships and the environmental sustainability. To that end, the search was limited to articles published in the fields of "Business, Management, and Accounting", "Social Science", and "Environmental Science", up to 9.8.2017 (search date), resulting in 373 papers.

If we consider 2012 as the starting year for our analysis, we obtain 262 articles. This year has a special meaning in terms of sustainability and environment because of the United Nations Conference on Sustainable Development (UNCSD), Rio+20, held in Rio de Janeiro, Brazil (United Nations, 2012a), which marked the beginning of the 17 Sustainable Development Goals (SDGs) and Agenda 2030 (United Nations, 2015a) process, considered a landmark for including sustainable development in the long-term global agenda and for the commitment of governments and society to turn words into actions (Schmalzbauer \& Visbeck, 2017).

In a preliminary stage of the study, without a time interval, we searched the same keywords and a single article was identified, published in 2011 under the title "Responsible Cruise Tourism: Issues of Cruise Tourism and Sustainability" (Klein, 2011). In this article, Klein discusses the impacts of cruise tourism on coastal and marine environments and analyses the need for responsible tourism, including economic, sociocultural, and environmental aspects. In this con- 
text the author emphasizes the need to control the causes of environmental impacts, such as liquid, solid waste, and burning fossil fuel emissions. The author also suggests the need for greater transparency on the part of shipping companies about their environmental practices, demonstrating corporate responsibility.

From the analysis of these studies, we selected and evaluated twelve articles, since they presented content related to sustainable development and sustainability, particularly in the scope of environmental sustainability of cruise ships, addressed in this research.

Some articles were not open access which limited the analysis to the title, abstract, and keywords. However, in the survey universe, it was possible to identify and have full access to the twelve articles in Scopus that addressed the topics searched. The analysis of the contents of the manuscripts prioritized the identification and confirmation of the environmental requirements, presented previously in this study: input management; waste management; air quality; energy management; water management; and transparency and their respective variables, factors that must be managed by the shipping companies to minimize the impacts of their ships.

The analysis of these twelve articles retrieved from Scopus confirmed the environmental requirements presented by this study, e.g. the reduction of environmental impacts is highlighted in the studies by Hearin et al. (2015) and Tribou and Swain (2015), who discuss the advantage of weekly grooming the ships' hull panels, providing the release of fouling materials and thus re- ducing fuel consumption and impacts on the environment

The reduction of fuel consumption is also emphasized by Acciaro (2014), who presents a model that suggests that the use of LNG (Liquefied Natural Gas) as fuel in ships could already be economically viable, cost-effective, from 2015. Lower fuel consumption becomes relevant because it has a direct impact on the reduction of air emissions, gases and noises (ABNT, 2014; ISO, 2016b) and in this context Bouman et al. (2017) and Schembari et al. (2012) carried out studies on $\mathrm{CO}_{2}$ emissions, aiming to identify practices that reduce environmental impacts caused by cargo and passenger shipping, and thus contributing to the reduction of emissions in the marine environment while sailing or when docked at a port.

Air pollution is also emphasized in Schembari et al.'s (2014) study that tries to identify the sources of aerosol, with the use of different analysis techniques to retrieve the PM10 composition (Particulate Matter) (EPA, 2017) in ships emissions. Waste management is addressed in the analysis of impacts caused by the materials used on board and disposal (input and output) by Strazza et al. (2015a). They analyzed the consumption of paper, and the possibility of reducing this consumption through the adoption of alternative substitution, or elimination; also by Strazza et al. (2015b), a study of the alternative use of recycled food waste as feed for aquaculture and, finally, by Strazza et al. (2016) the evaluation of the potential environmental impacts of switching packaging material, from glass to plastic, of water bottles.

Jones et al. (2016a, 2016b) highlight 
the transparency of cruise lines reflected in their sustainability reports, notably the Carnival Corporation and Royal Caribbean Cruises, the only companies that provide information about sustainability. The authors point out that other companies, among the best ranked in the cruise industry, publish limited, if any, information on their websites about the topic. Moreover, in a critical sense, the authors state that shipping companies do not include sustainability in their strategic scope and, instead, underline the economic outcomes without due attention to the protection and maintenance of the natural environment.

In order to fulfil the main objective of research, which is to identify publications focusing on environmental requirements, in a first moment we have analyzed 12 articles from which 65 keywords emerged, identifying the most researched subjects, and indicating their relevance in the respective studies. Table 1 presents the themes addressed based on the used keywords, grouped into two dimensions: Environmental and Others (Non-Environmental).

Table 1 presents in the Environmental group the concentration of $43.08 \%$ of keywords related to the environmental requirements specified previously in this study, which will serve to define variables or indicators that should be measured on a cruise ship. Of the six requirements related to this research, five are identified in this group and presented next, along the respective keywords used: Waste management (waste minimization and waste reduction); Air quality (abatement options, emission reductions and carbon footprint, ship emissions); Energy management (antifouling coatings); Water management (water footprint) and Transparency (EPD).

When analyzing these keywords and relating them to the requirements, it was verified that the input management requirement is not mentioned directly in this group, although indirectly it appears in the study by Strazza et al. (2015a), when the authors analyze alternatives for reducing the consumption of paper on board the ships. This reduction could impact the input of such material; however, the keywords are related to the output, regarding the waste management requirement.

The continuous improvement in reducing waste production should consider also the causes of the impacts and not only the effects (Fodness, 2016), therefore, when analyzing the consumption of materials on board, both output and input management must be performed by specifying and controlling the materials that enter a ship, including product packaging, fuels, cleaning products, among others.

Other keywords are used in the Environment group; however, they refer to general aspects of this dimension: environment, green shipping, industrial ecology and shipping, and the environment. Above all, it should be noted that there are few studies that include the six requirements regarding the environmental responsibility of cruise ships. 
Table 1 - Dimensions and frequency of Keywords (10.08.2017)

\begin{tabular}{|c|c|c|c|}
\hline Dimension & Keyword & $\begin{array}{c}\text { Repeti- } \\
\text { tions }\end{array}$ & Frequency (\%) \\
\hline \multirow{28}{*}{ Environmental } & Ship emissions & 2 & $3.08 \%$ \\
\hline & Abatement options & 1 & $1.54 \%$ \\
\hline & Air quality & 1 & $1.54 \%$ \\
\hline & Antifouling coatings & 1 & $1.54 \%$ \\
\hline & Biofilms & 1 & $1.54 \%$ \\
\hline & Biofouling & 1 & $1.54 \%$ \\
\hline & Carbon footprint & 1 & $1.54 \%$ \\
\hline & Emission reductions & 1 & $1.54 \%$ \\
\hline & Environment & 1 & $1.54 \%$ \\
\hline & EPD (Environmental Product Declarations) & 1 & $1.54 \%$ \\
\hline & Fouling & 1 & $1.54 \%$ \\
\hline & Fouling release coatings & 1 & $1.54 \%$ \\
\hline & Green shipping & 1 & $1.54 \%$ \\
\hline & Greenhouse gases & 1 & $1.54 \%$ \\
\hline & Industrial ecology & 1 & $1.54 \%$ \\
\hline & Macrofouling & 1 & $1.54 \%$ \\
\hline & Paper waste & 1 & $1.54 \%$ \\
\hline & PM10 & 1 & $1.54 \%$ \\
\hline & Shipping and the environment & 1 & $1.54 \%$ \\
\hline & Sox & 1 & $1.54 \%$ \\
\hline & Sulphur dioxide & 1 & $1.54 \%$ \\
\hline & Sulphur emissions & 1 & $1.54 \%$ \\
\hline & Sustainability & 1 & $1,54 \%$ \\
\hline & Waste & 1 & $1.54 \%$ \\
\hline & Waste minimization & 1 & $1.54 \%$ \\
\hline & Waste reduction & 1 & $1.54 \%$ \\
\hline & Water footprint & 1 & $1.54 \%$ \\
\hline & & 28 & $43.08 \%$ \\
\hline \multirow[t]{2}{*}{$\begin{array}{c}\text { Others } \\
\text { non environ- } \\
\text { mental }\end{array}$} & $\begin{array}{l}\text { Adhesion, Assurance, Bottled water, Brush, Com- } \\
\text { munities, Conjoint analysis, Consumer behavior } \\
\text { decision making, Corporate social responsibility, } \\
\text { Corporate sustainability, Cradle-to-cradle, Cruise } \\
\text { (2), Digitalization, Expedition cruising, Factoriza- } \\
\text { tion, Feed, Glass, Grooming, Harbors, Interpreta- } \\
\text { tion, LCA (Life Cycle assessment), Life cycle as- } \\
\text { sessment, LNG retrofit, Maritime transport, Ma- } \\
\text { teriality, Means-end analysis, Mediterranean, } \\
\text { Mediterranean Sea, Ocean cruising industry, } \\
\text { Plastic, Positive matrix, Real options, Shear } \\
\text { stress, Ship hull, Ship hull grooming, Source ap- } \\
\text { pointment, Sustainability, Tourist experiences, } \\
\text { Tourist industry. }\end{array}$ & 37 & $56.92 \%$ \\
\hline & & 65 & $100.00 \%$ \\
\hline
\end{tabular}

Source: The authors

Finally, the Others - Non-Environ- are not directly related to environmental susmental group presents the largest number of tainability, one of the main dimensions anadimensions studied by researchers, with lyzed in this article, showing weak conver$56.92 \%$ of the keywords used, however, they gence between the topics surveyed. The lack 
of repeated keywords should be noted, occurring only in the cases of 'cruise' and 'ship emissions', both used twice. This means that research on cruise ships environmental sustainability is still scarce and that there is not a significant number focusing on common subjects.

Another noteworthy feature is the approach to the Transparency requirement (Jones, Comfort, et al., 2016; Jones, Hillier, et al., 2016). Being transparent and providing information about environmental practices can help perceive cruisers as spokespersons on behalf of the positive impacts generated by cruise lines. However, negative impacts, if they occur, may also be disclosed causing great damage to the organizational image, since reputation may be affected by facts, or even by intentions, and thus negative perceptions may become associated with the organization (Carpenter, 2014, Frandsen, 2017).

Despite this, sustainability indexes should not be kept secret because information is key in raising awareness and changing perception of this topic (ABNT, 2014, 2015; Ballantyne, Packer, \& Falk, 2011; Choi \& Murray, 2010; De Conto, Corrêa, Pessin, Zaro, \& Baptista, 2013; FEE, 2017; GSTC, 2017; Neiman, Barbosa Frederico, \& Pereira, 2012; Pedrini, Brotto, Ghilardi-Lopes, Lopes, \& Ferreira, 2015; Silva \& Maracajá, 2012; UNEP, 2005; Zhang, Cole, \& Chancellor, 2013) and promoting an active engagement with the needs of the planet and a better future for all.

Therefore, in the second stage in order to verify the strategic predisposition of shipping companies towards environmental practices, we sought to identify on the websites of the 31 CLIA-associated cruise companies (CLIA, 2017) whether these shipping companies communicated their environmental attitudes to the market.

Although websites are not the only channels of communication, the authors assume them as the main communication channel of the shipping companies with cruise customers. This assumption is based on the professional experience of one of the authors of this research, who worked for ten years both as cruise operator, selling travel packages to the travel agencies, and as a travel agent, selling the packages to the final customers.

The analysis of the companies' websites revealed that, in general, companies focus on fleet characteristics, itineraries, onboard attractions, and package prices without worrying about providing information on environmental performance practices, initiatives, and reports. Only seven (22.6\%) (Aida Cruises, Carnival Cruise Line, Celebrity Cruises, Costa Cruise Line, Holland America Line, Royal Caribbean and TUI Cruises) of the 31 companies examined offer a specific link to access information on environmentally sustainable practices and only five (16.1\%) (Carnival Cruise Line, Costa Cruise Line, Royal Caribbean and TUI Cruises) provide information to the consumer market about the requirements and indicators of environmental sustainability.

For potential customers wishing to contact to obtain information about the practices adopted and the environmental benefits achieved by companies, only three (9.7\%) of the 31 cruise lines offer this possibility. 
These figures are a wake-up call to cruise companies that choose not to provide information about their environmental initiatives, ignoring this new environmentally aware consumer that takes other factors into consideration in their decision-making process besides price (Ambec, Cohen, Elgie, \& Lanoie, 2013; Dobbs, 2014; Doh, Lawton, \& Rajwani, 2012; Porter, 1986; C. E. A. Ramoa, Ardigó, \& Flores, 2016). Therefore, knowing that this customer is looking for value rather than price (Aaker \& McLoughlin, 2010; Lee \& Yoo, 2015; Walker \& Moscardo, 2014) organizations should consider that positive environmental factors can improve their image vis-à-vis the market and can be interpreted as an added value that will attract consumers (Gössling, Hall, Ekström, Engeset, \& Aall, 2012; Lima, Cunha, Moreira, \& Porte, 2012; Melissen, 2013; Moriarty, 2012; L. R. de Oliveira, Martins, \& Lima, 2010; L. R. Oliveira et al., 2012; Pomeringa, Noblea, \& Johnson, 2011).

\section{CONCLUSIONS}

The topic of sustainability is still relatively new to the international scene. Aldo Leopold in his 1949 book Sand County Almanac (Leopold, 1968), expressed the need to respect the land, water, plants, and animals; years later, in 1962, Rachel Carson in her book Silent Spring (Carson, 1962), drew attention to the harmful effects of the indiscriminate use of agrochemicals in agriculture. It took ten years until the UN created the United Nations Environment Program, in 1972 (UNEP, 2002).

With the creation of the UNEP, sus- tainability started to be taken more seriously, mainly after the concept of sustainable development became formalized, in 1980 (Gavard, 2009; IUCN, 1980). This provocative theme has gained momentum, form, and international repercussion from the UN Conferences and it is now being discussed more effectively by organizations due to the definition of the goals and targets of the 2030 Agenda (United Nations, 2015c).

The theme is broad and causes much discussion, including in the tourism industry. The various sectors of the economy require strategies that, besides profit, focus also on sociocultural and environmental aspects, aiming to achieve growth and sustainable development to meet the wishes and needs of current and future generations with a better quality of life.

Organizations must address the sustainable development criteria in their strategic planning, taking their responsibilities seriously according to an in-depth analysis of the 2030 Agenda.

However, based on the premise that cruise ships should adopt the best environmental practices as a principle (Fodness, 2016; United Nations, 2015b), this study found that only $22.58 \%$ of the companies surveyed are transparent in their communications about environmental practices to the point where they can strategically influence current and potential customers in their process of choosing environmentally-friendly tourism products, which highlights the gap between companies and consumers.

It is identified as a limitation of this research the use of a single communication channel as a source of inquiry to verify the 
strategic predisposition of shipping companies towards environmental practices, although from an academic perspective, the findings show that cruise tourism research, particularly studies addressing environmental sustainability on ships, is still limited. Thus, the topic is far from being exhausted or well-established among the researchers.

In both cases, despite its importance and the efforts of several organizations in the promotion of sustainable practices (ABNT, 2015; Boell, 2017; DKN Future Earth, 2017; FEE, 2017; Friends of Earth, 2017; GRI, 2018; GSTC, 2017; IMO, 2017; ISO, 2016a; IUCN, 2017; United Nations, 2016d), the theme must bring together all stakeholders in order to foster technical and scientific studies and promote sustainable behavior at all levels, becoming an agent of change and an inspiration for governments, corporations, academia, and society.

Although there is no better way (Mintzberg et al., 2007), or a standard approach in the formation of sustainability strategies (Almeida, Agostinho, Giannetti, \& Huisingh, 2015) this study hopes to inspire the development of a management model that considers the environmental sustainability dimension as a strategic value to be incorporated into the cruise industry and ship cruises, helping shipping companies understand the environment in which they operate, in order to face the economic, social, and environmental challenges and their relationships.

This study is focused on environmental sustainability, but it did not intend to underestimate the other dimensions of TBL. However, it is worth noting the importance of drawing the cruise companies' attention to their responsibility for the conservation of the marine environment and the impacts on destinations visited.

Therefore, this strategy, as suggested by Almeida et al. (2015), even if implemented individually, can help achieve the goals and targets of sustainable development by integrating cleaner cruise operations with the marine environment.

Finally, it is expected that the findings can contribute to the adoption of environmental responsibility as a principle by organizations, not only by the cruise industry, but also by other tourism players, particularly the hotel industry and destination management organizations, and also to encourage further research on environmental sustainability in particular, or on SDGs in a broader perspective.

\section{ACKNOWLEDGMENTS}

This work was supported by CAPES scholarship/Doctoral 'Sandwich' Program Abroad /Process No. \{88881.134585/2016$01\}$

\section{REFERENCES}

Aaker, D. A., \& McLoughlin, D. (2010). Strategic market management: global perspectives. West Sussex: Wiley.

ABNT. (2014). ABNT NBR 15401:2014. Meios de hospedagem. Sistema de gestão da sustentabilidade. Requisitos. São Paulo: ABNT. ABNT. (2015). ABNT NBR ISO 14001:2015. Sistemas de gestão ambiental. São Paulo: ABNT.

Acciaro, M. (2014). A real option application to investment in low-sulphur maritime transport. 
International Journal of Shipping and Transport Logistics, 6(2), doi:10.1504/IJSTL.2014.059570

Adams, S.-A., Font, X., \& Stanford, D. (2017). All aboard the corporate socially and environmentally responsible cruise ship. Worldwide Hospitality and Tourism Themes, 9(1), 31-43. doi:10.1108/WHATT-11-2016-0061

Agarwal, S. (2002). Restructuring seaside tourism: The Resort Lifecyle. Annals of Tourism Research, 29(1), 25-55.

Almeida, C. M. V. B., Agostinho, F., Giannetti, B. F., \& Huisingh, D. (2015). Integrating cleaner production into sustainability strategies: an introduction to this special volume. Journal of Cleaner Production, 96, 1-9. doi:10.1016/j.jclepro.2014.11.083

Alves, R. P., \& Hanazaki, N. (2015). Áreas protegidas marinho-costeiras de Santa Catarina sob a perspectiva das populações locais: Contribuições da literatura. Ambiente \& Sociedade, 18(4), 97-118.

Ambec, S., Cohen, M. A., Elgie, S., \& Lanoie, P. (2013). The Porter Hypothesis at 20: Can Environmental Regulation Enhance Innovation and Competitiveness? Review of Environmental Economics and Policy, 7(1), 2-22. doi:10.1093/reep/res016

Ardoin, N. M., Wheaton, M., Bowers, A. W., Hunt, C. A., \& Durham, W. H. (2015). Nature-based tourism's impact on environmental knowledge, attitudes, and behavior: a review and analysis of the literature and potential future research. Journal of Sustainable Tourism, 23(6), 838-858. doi:10.1080/09669582.2015.1024258

Ballantyne, R., Packer, J., \& Falk, J. (2011). Visitors' learning for environmental sustainability: Testing short- and long-term impacts of wildlife tourism experiences using structural equation modelling. Tourism Management, 32(6), 1243-1252. doi:10.1016/j.tourman.2010.11.003
Bellen, H. M. van. (2007). Indicadores de sustentabilidade: uma análise comparativa (2nd ed.). Rio de Janeiro: FGV.

Boell. (2017). Heinrich Böll Foundation. Retrieved January 28, 2018, from https://www.boell.de/en

Bonilla-Priego, M. J., Font, X., \& PachecoOlivares, M. del R. (2014). Corporate sustainability reporting index and baseline data for the cruise industry. Tourism Management, 44, 149-160. doi:10.1016/j.tourman.2014.03.004

Bouman, E. A., Lindstad, E., Rialland, A. I., \& Strømman, A. H. (2017). State-of-the-art technologies, measures, and potential for reducing GHG emissions from shipping - A review. Transportation Research Part D: Transport and Environment, 52, 408-421. doi:10.1016/j.trd.2017.03.022

Brasil. (2017). Comissão Nacional para os ODS. Plano de Ação 2017-2019. Brasília: Comissão Nacional para os ODS.

Brida, J. G., Chiappa, G. Del, Meleddu, M., \& Pulina, M. (2012). A Comparison of Residents' Perceptions in Two Cruise Ports in the Mediterranean Sea. International Journal of Tourism Research, 16(2), 180-190. doi:10.1002/jtr.1915

Brotto, D. S., Pimentel, D. D. S., Behrends, E., Alves, A., \& Moraes, J. De. (2016). Transformative and Emancipatory Environmental Education by Marine Ecotourism in the Marine Environmental Protection Area of Armação dos Búzios (RJ , Brazil). Revista Brasileira de Ecoturismo, 9(3), 445-470.

Buckley, R. (2012). Sustainable tourism: Research and reality. Annals of Tourism Research, 39(2), 528-546. doi:10.1016/j.annals.2012.02.003

Carson, R. (1962). Primavera silenciosa (2nd ed.). São Paulo: Melhoramentos.

Chiu, Y.-T. H., Lee, W.-I., \& Chen, T.-H. (2013). Environmentally Responsible Behavior in 
Ecotourism: Exploring the Role of Destination Image and Value Perception. Asia Pacific Journal of Tourism Research, 198(8), 876-889. doi:10.1080/10941665.2013.818048

Choi, H. C., \& Murray, I. (2010). Resident attitudes toward sustainable community tourism. Journal of Sustainable Tourism, 18(4), 575-594. doi:10.1080/09669580903524852

CLIA. (2016a). Cruise industry outlook. Retrieved January 14, 2018, from http://www.cruising.org/docs/defaultsource/research/2016_clia_sotci.pdf?sfvrsn=0

CLIA. (2016b). CLIA Environment Sustainability Report 2016. Retrieved January 14, 2018, from http://cruising.org/docs/defaultsource/research/clia_2016_envsust_8-5x11_88.pdf?sfvrsn $=0$

CLIA. (2018). Cruise Line Members. Retrieved January 27, 2018, from https://www.cruising.org/cruisevacationer/member-cruise-lines

CLIA Brasil. (2018). Associados. Retrieved December 14, 2017, from http://www.abremar.com.br/clia-abremarbrasil/

CLIA Europe. (2015). The cruise industry: Contribution of Cruise Tourism to the Economies of Europe 2015 Edition. Retrieved September 14, 2017, from http://www.cliaeurope.eu/images/downloads/r eports/CLIA_Europe_Economic_Contribution_Re port_2015.pdf

Coggins Jr, A. O. (2014). The globalization of the cruise industry: a tale of ships. Worldwide Hospitality and Tourism Themes, 6(2), 138-151. doi:10.1108/WHATT-12-2013-0048

Cooper, D., \& Schindler, P. S. (2003). Métodos de pesquisa em administracao (7th ed.). Porto Alegre: Bookman Editora.

Costa Cruises. (2015). Costa cruises: sustainability report: results for 2015 and outlook for the future. Genova: Costa Cruises.

Crespo, S. (2015). O Brasil na era verde: a consciência ecológica no país segundo pesquisas de opinião. Opinião Pública, 1(2), 120-148.

Creswell, J. W., \& Poth, C. N. (2016). Qualitative inquiry and research design: choosing among Five Approaches. SAGE Publications.

Cruise Market Watch. (2018). Worldwide Cruise Line Market Share. Retrieved January 25, 2018, from

http://www.cruisemarketwatch.com/marketshare/

Daly, H., \& Cobb, J. B. (1994). For the common good. Boston: Beacon Press.

Daly, H. E. (1990). Toward some operational principles of sustainable development. Ecological Economics, 2, 1-6.

De Conto, S. M., Corrêa, L. B., Pessin, N., Zaro, M., \& Baptista, M. T. (2013). Educación ambiental en medios de hospedaje Información de los huéspedes en Caxias do Sul, Brasil. Estudios y Perspectivas En Turismo, 22, 473-491.

DKN Future Earth. (2017). Deutsches Komitee für Nachhaltigkeitsforschung in Future Earth. About us. Retrieved December 28, 2017, from http://www.dkn-future-

earth.org/en/committee/about-us/

Dobbs, M. (2014). Guidelines for applying Porter's five forces framework: a set of industry analysis templates. Competitiveness Review, 24(1), 32-45. doi:10.1108/CR-06-2013-0059

Doh, J. P., Lawton, T. C., \& Rajwani, T. (2012). Advancing Nonmarket Strategy Research: Institutional Perspectives in a Changing World. Academy of Management Perspectives, 26(3), 22-39. doi:10.5465/amp.2012.0041

Doran, R., \& Larsen, S. (2014). Are we all environmental tourists now? The role of biases in social comparison across and within tourists, and 
their implications. Journal of Sustainable Tourism, 22(7), doi:10.1080/09669582.2013.836209

Dowling, R. (2006). The cruise industry. In Cruise ship tourism (pp. 3-17). Joondaloop, Austrália: Cohan University. School of marketing, leisure and tourism.

Elkington, J. (2012). Sustentabilidade, canibais com garfo e faca. São Paulo: M. Books do Brasil.

EPA. (2017). United States environmental protection agency. Particulate Matter (PM10). Retrieved from https://www.epa.gov/airtrends/particulate-matter-pm10-trends

FEE. (2017). Foundation for environmental education. Retrieved December 5, 2017, from http://www.fee.global/

FGV. (2016). Cruzeiros marítimos: estudo de perfil e impactos econômicos no Brasil. Temporada 2015-2016. Rio de Janeiro: FGV.

Fodness, D. (2016). The problematic nature of sustainable tourism: some implications for planners and managers. Current Issues in Tourism, 1-13. doi:10.1080/13683500.2016.1209162

Fonseca, C. R. D. da. (2012). Cruzeiros marítimos de cabotagem e a regulamentação da atividade no Brasil. Universidade Federal Fluminense, Niterói.

Friends of Earth. (2016). Cruise ship report card. Cruise Lines. Retrieved December 14, 2017, from http://www.foe.org/cruise-report-card

Friends of Earth. (2017). Friends of Earth. About Us. Retrieved December 9, 2017, from http://www.foe.org/about-us

Gavard, F. M. P. (2009). Do impasse ao consenso: um breve histórico do conceito de desenvolvimento sustentável. Revista Sociais $e$ Humanas, 22(2).

Gibson, P. (2012). Cruise operations management: hospitality perspectives. Abingdon: Routledge.

Godemann, J., \& Michelsen, G. (2011). Sustainability communication: an introduction: in sustainability communication (pp. 3-11). Dordrecht: Springer Netherlands. doi:10.1007/978-94-007-1697-1_1

Goodland, R. (1995). The concept of environmental sustainability. Annual Review of Ecology and Systematics, 26(1), 1-24. doi:10.1146/annurev.es.26.110195.000245

Goodland, R. (2002). Sustainability: human, social, economic and environmental. Encyclopedia of Global Environmental Change.

Goodland, R., \& Daly, H. (1996). Environmental sustainability: universal and non-negotiable. Ecological Applications, 6(4), 1002-1017.

Gopal, S. (2014). Environmental sustainability: the tour operator's perceptions. Tourismos, 9(1), 127-143.

Gössling, S., Hall, C. M., Ekström, F., Engeset, A. B., \& Aall, C. (2012). Transition management: a tool for implementing sustainable tourism scenarios? Journal of Sustainable Tourism, 20(6), 899-916. doi:10.1080/09669582.2012.699062

Gössling, S., \& Peeters, P. (2015). Assessing tourism's global environmental impact 19002050. Journal of Sustainable Tourism, 23(5), 639659. doi:10.1080/09669582.2015.1008500

GRI. (2013). New G4 content index tool and other useful G4 related resources. Retrieved January 14, 2018, from https://www.globalreporting.org/information/n ews-and-press-center/Pages/New-G4-ContentIndex-Tool-and-other-useful-G4-relatedresources.aspx

GRI. (2018). Global Reporting Initiative. About GRI. Retrieved February 9, 2018, from https://www.globalreporting.org/Information/a bout-gri/Pages/default.aspx 
GSTC. (2017). Global Sustainable Tourism Council (GSTC). About us. Retrieved December 5, 2017, from https://www.gstcouncil.org/about/aboutus/

Hall, C. M., Wood, H., \& Wilson, S. (2017). Environmental reporting in the cruise industry. In R. Dowling \& C. Weeden (Eds.), Cruise Ship Tourism (2nd ed., pp. 441-464). Boston: CABI. doi:10.1079/9781780646084.0441

Hearin, J., Hunsucker, K. Z., Swain, G., Stephens, A., Gardner, H., Lieberman, K., \& Harper, M. (2015). Analysis of long-term mechanical grooming on large-scale test panels coated with an antifouling and a fouling-release coating. Biofouling, 31(8), 625-638. doi:10.1080/08927014.2015.1081687

Herzig, C., \& Schaltegger, S. (2011). Corporate Sustainability Reporting. In Sustainability Communication (pp. 151-169). Dordrecht: Springer Netherlands. doi:10.1007/978-94-0071697-1_14

Hwang, J., \& Han, H. (2014). Examining strategies for maximizing and utilizing brand prestige in the luxury cruise industry. Tourism Management, 40, 244-259. doi:10.1016/j.tourman.2013.06.007

ICSU. (2017). A Guide to SDG Interactions: from Science to Implementation. (D. J. Griggs, M. Nilsson, A. Stevance, \& D. McCollum, Eds.). Paris: International Council for Science. doi:10.24948/2017.01

IMO. (1980). International Convention for the Safety of Life at Sea (SOLAS). London: International Maritime Organization.

IMO. (2016a). MARPOL. Annex I - Regulations for the Prevention of Pollution by Oil. London: International Maritime Organization.

IMO. (2016b). MARPOL. Annex IV- Regulations for the Prevention of Pollution by Sewage from Ships. London: International Maritime Organization.

IMO. (2016c). MARPOL. Annex V- Regulations for the Prevention of Pollution by Garbage from Ships. London: International Maritime Organization.

IMO. (2016d). MARPOL. Annex VI- Regulations for the Prevention of Air Pollution from Ship. London: International Maritime Organization.

IMO. (2016e). Our Work. Marine Environment. Ballast Water Management. London: International Maritime Organization.

IMO. (2017). History of IMO. London: International Maritime Organization.

ISO. (2014). ISO 14046:2014. Environmental management. Water footprint. Principles, requirements and guidelines. Geneve: International Standard Organization.

ISO. (2016a). ISO 14001:2015 - Environmental management systems. Requirements with guidance for use. Geneve: International Standard Organization.

ISO. (2016b). ISO 50001. Energy management. Geneve: International Standard Organization.

IUCN. (1980). World Conservation Strategy: living resource conservation for sustainable development. Gland: IUCN.

IUCN. (2017). International Union for Conservation of Nature. About. Gland: IUCN.

Jäckel, K., Fodor, M., \& Papp, J. (2015). Environment conscious consumers' opinion on selective waste management. Journal of Contemporary Economic and Business Issues, $2(2), 5-22$.

Jones, P., Comfort, D., \& Hillier, D. (2016). Sustainability and the world's leading ocean cruising companies. Journal of Public Affairs, 110. doi:10.1002/pa.1609

Jones, P., Hillier, D., \& Comfort, D. (2016). The two market leaders in ocean cruising and corporate sustainability. International Journal of 
Contemporary Hospitality Management, 29(1), 288-306. doi:10.1108/IJCHM-04-2016-0191

Kerswill, M., \& Mair, H. (2015). Big Ships, Small Towns: Understanding Cruise Port Development in Falmouth, Jamaica. Tourism in Marine Environments, 10(3), 189-199. doi:10.3727/154427315X14181438892766

Khan, M. A., Boër, B., Özturk, M., Clüsener-Godt, M., Gul, B., \& Breckle, S. W. (2016). Sabkha Ecosystems: Volume V: The Americas. Doha: Springer International Publishing.

Klein, R. A. (2009). Getting a Grip on Cruise Ship Pollution. Amsterdam: Friends of the Earth.

Klein, R. A. (2010). Chapter 6 The cruise sector and its environmental impact. In C. Schott (Ed.), Bridging Tourism Theory and Practice (pp. 113130). Somerville: Emerald Group Publishing Limited.doi:10.1108/S2042-

1443(2010)0000003009

Klein, R. A. (2011). Responsible Cruise Tourism: Issues of Cruise Tourism and Sustainability. Journal of Hospitality and Tourism Management, 18(1), 107-116. doi:10.1375/jhtm.18.1.107

Kuščer, K. (2013). Determining factors of mountain destination innovativeness. Journal of Vacation Marketing, 19(1), 41-54. doi:10.1177/1356766712461404

Lee, M.-K., \& Yoo, S.-H. (2015). Using a Choice Experiment (CE) to Value the Attributes of Cruise Tourism. Journal of Travel \& Tourism Marketing, 32(4),416-427.

doi:10.1080/10548408.2014.904259

Leopold, A. (1968). A Sand County Almanac: With Other Essays on Conservation from Round River. New York: Oxford University Press.

Lima, K. P. S. de, Cunha, D. R., Moreira, F. G. L., \& Porte, M. de S. (2012). Contabilidade ambiental: um estudo sobre a evidenciação das informações ambientais nas demonstrações contábeis das grandes empresas brasileiras. Revista Eletrônica de Administração, 11(1), 1-14.

Lin, L.-P. (Lynn). (2017). Industrial tourists' behavioral intention toward slow travel in Taiwan. Journal of Sustainable Tourism, 25(3), 379-396. doi:10.1080/09669582.2016.1213848

Lindgren, J. F., Wilewska-Bien, M., Granhag, L., Andersson, K., \& Eriksson, K. M. (2016). Discharges to the Sea. In K. Andersson, S. Brynolf, F. J. Lindgren, \& M. Wilewska-Bien (Eds.), Shipping and the Environment: Improving Environmental Performance in Marine Transportation (pp. 125-168). Berlin, Heidelberg: Springer Berlin Heidelberg. doi:10.1007/978-3662-49045-7_4

Lohmann, G., \& Panosso-Netto, A. (2012). Teoria do Turismo. São Paulo: Aleph.

Mancini, M. (2011). The CLIA guide to the cruise industry. New York: Cengage Learning.

Marzo-Navarro, M., Pedraja-Iglesias, M., \& Vinzón, L. (2015). Sustainability indicators of rural tourism from the perspective of the residents. Tourism Geographies, 17(4), 586-602. doi:10.1080/14616688.2015.1062909

Melissen, F. (2013). Sustainable hospitality: A meaningful notion? Journal of Sustainable Tourism, 21(6), 810-824. doi:Melissen, F. (2013). Sustainable hospitality: A meaningful notion? Journal of Sustainable Tourism, 21(6), 810-824. Retrieved from 10.1080/09669582.2012.737797

Mendes, J., \& Silva, N. (2012). O turismo de cruzeiros em Portugal. O caso de Portimão: expectativas e desafios. In Abordagem Multidisciplinar dos Cruzeiros Turísticos (pp. 135-154). Leiria: Textiverso, Lda.

Mintzberg, H., Lampel, J., Quinn, J. B., \& Ghoshal, S. (2007). O Processo da Estratégia: conceitos, contextos e casos selecionados (4th ed.). Porto Alegre: Bookman.

Miranda, C. de S., Santos, R. de O. J. dos, Gomes, E. J., Fernandez, L. R. G., \& Lourenção, M. T. de A. 
(2015). Informações de mercado para tomada de decisão: uma avaliação de empresas do setor de turismo e hospitalidade. Reuna, 20(4), 67-92.

Moriarty, J. P. (2012). Theorising scenario analysis to improve future perspective planning in tourism. Journal of Sustainable Tourism, 20(6), 779-800. doi:10.1080/09669582.2012.673619

NABU. (2017). Air pollution from Ships. Berlin: Nature and Biodiversity Conservation Union.

Najafipour, A. A., Marzi, V., \& Foroozanfar, M. H. (2014). The Future of Cruise Ship Tourism Industry: the challenges of cruising market and operations management. Journal of Social Issues \& Humanities, 2(7), 213-224.

Neiman, Z., Barbosa Frederico, I., \& Pereira, J. C. (2012). La educacion ambiental a traves de las actividades de turismo educativo en la ensenanza superior. Estudios y Perspectivas En Turismo, 21(2), 478-494.

Oliveira, L. R. de, Martins, E. F., \& Lima, G. B. A. (2010). Evolução do conceito de sustentabilidade: um ensaio bibliométrico. Relatórios de Pesquisa Em Engenharia de Produção, 10(4), 1-17.

Oliveira, L. R., Medeiros, R. M., Terra, P. de B., \& Quelhas, O. L. G. (2012). Sustentabilidade: da evolução dos conceitos à implementação como estratégia nas organizações. Production, 22(1), 70-82. doi:10.1590/S0103-65132011005000062

Oliveira, W. A., \& Da Silva, C. B. (2016). Análise da Imagem dos Turistas quanto ao Desenvolvimento do Turismo em Perobas, Touros-RN. Revista Turismo Em Análise, 27(2), 414. doi:10.11606/issn.1984-4867.v27i2p414-428

OMT. (2008). Turismo de cruceros. Situación actual y tendencias. Madrid: Organización Mundial del Turismo. doi:10.18111/9789284412402

Panosso-Netto, A., \& Trigo, L. G. G. (2009). Cenários do turismo brasileiro. São Paulo: Aleph.
Papatheodorou, A. (2004). Exploring the evolution of tourism resorts. Annals of Tourism Research, 31(1), 219-237. doi:10.1016/j.annals.2003.10.004

Pavlić, I. (2013). Cruise tourism demand forecasting - the case of Dubrovnik. Tourism and Hospitality Management, 19.(1.), 125-142.

Pedrini, A. d. G., Brotto, D. S., Ghilardi-Lopes, N. P., Lopes, M. C., \& Ferreira, L. P. (2015). Environmental education and ecotourism concepts in Marine Protected Area of Armação de Búzios, Rio de Janeiro, Brazil: reflections for the adoption of coastal ecotourism. Revista Brasileira de Ecoturismo, 8(1), 59-73.

Pirajá, C. M. P. (2015). A zona costeira brasileira como área de proteção às tartarugas marinhas. Revista Direito e Política, 2(3), 291-309.

Pires, P. S. (2012). Sustentabilidade: dimensão ambiental. In M. C. Beni (Ed.), Turismo: planejamento estratégico e capacidade de gestão - desenvolvimento regional de produção e clusters (pp. 181-202). São Paulo: Manole.

Pomeringa, A., Noblea, G., \& Johnson, L. W. (2011). Conceptualising a contemporary marketing mix for sustainable tourism.: EBSCOhost. Journal of Sustainable Tourism, 19(8), 953-969.

doi:10.1080/09669582.2011.584625

Porter, M. (1986). Estratégia competitiva: técnicas para análise de indústrias e da concorrência. Rio de Janeiro: Campus.

Ramoa, C. E. A., Ardigó, C. M., \& Flores, L. C. S. (2016). PESQUISA DE MARCA: a Marca País em uma análise nos principais periódicos brasileiros do turismo publicados até maio/2016. In XIII Seminário Anptur (p. 16). São Paulo: Associação Nacional de Pesquisadores em Turismo.

Ramoa, C. E. de A., \& Flores, L. C. da S. (2015). Cruzeiros marítimos: tendência da demanda no mercado brasileiro e internacional para os próximos 5 anos, a partir de 2014. Observatório 
de La Economia Latinoamericana, 206.

Rodrigues, A. L. O., Rodrigues, A., \& Peroff, D. M. (2015). The Sky and Sustainable Tourism Development: A Case Study of a Dark Sky Reserve Implementation in Alqueva. International Journal of Tourism Research, 17(3), 292-302. doi:10.1002/jtr.1987

Roe, P., Hrymak, V., \& Dimanche, F. (2014). Assessing environmental sustainability in tourism and recreation areas: a risk-assessment-based model. Journal of Sustainable Tourism, 22(2), 319-338. doi:10.1080/09669582.2013.815762

Rosa, F. S., \& Silva, L. C. (2017). Sustentabilidade ambiental nos hotéis, contribuição teórica e metodológica. Revista Brasileira de Pesquisa Em Turismo, 11(1), 39. doi:10.7784/rbtur.v11i1.1161

Rosalind Jenkins, N., \& Karanikola, I. (2014). Do hotel companies communicate their environmental policies and practices more than independent hotels in Dubai, UAE? Worldwide Hospitality and Tourism Themes, 6(4), 362-380. doi:10.1108/WHATT-01-2014-0003

Royal Caribbean. (2017). Royal Caribbean a commitment to oceans. Reporting GRI \& Performance Tables. Miramar: Royal Caribbean. Sachs, I. (1993). Estratégias de transição para o século XXI: desenvolvimento e meio ambiente. In Para pensar o desenvolvimento sustentável ( $p$. 161). São Paulo: Brasiliense.

Sachs, I. (2009). Caminhos para o desenvolvimento sustentável. Rio de Janeiro: Garamond.

Sampieri, R. H., Collado, C. F., \& Lucio, M. del P. B. (2013). Metodologia de pesquisa. Porto Alegre: Penso.

Santos, V. A. dos. (2009). Turismo brasileiro contemporâneo: o conflito entre cruzeiros e resorts. Universidade Federal Fluminense, Niterói.

Santos, G. E. de O., \& Silva, V. de J. (2015). Mapa perceptual como ferramenta para a análise da imagem de destinos turísticos. Revista de Turismo ContemporâNeo, 3(2), 211-231.

Schaltegger, S., Lüdeke-Freund, F., \& Hansen, E. G. (2016). Business Models for Sustainability: A Co-Evolutionary Analysis of Sustainable Entrepreneurship, Innovation, and Transformation. Organization \& Environment, 29(3), 264-289. doi:10.1177/1086026616633272

Schembari, C., Bove, M. C., Cuccia, E., Cavalli, F., Hjorth, J., Massabò, D., ... Prati, P. (2014). Source apportionment of PM10 in the Western Mediterranean based on observations from a cruise ship. Atmospheric Environment, 98, 510518. doi:10.1016/j.atmosenv.2014.09.015

Schembari, C., Cavalli, F., Cuccia, E., Hjorth, J., Calzolai, G., Pérez, N., ... Raes, F. (2012). Impact of a European directive on ship emissions on air quality in Mediterranean harbours. Atmospheric Environment, 61, 661-669. doi:10.1016/j.atmosenv.2012.06.047

Schmalzbauer, B., \& Visbeck, M. (2017). The contribution of science in implementing the Sustainable Development Goals. Stuttgart/Kiel: German Committee Future Earth.

Silva, G. B., \& Maracajá, K. F. B. (2012). A educação ambiental e a educação turística no ensino fundamental na Escola Estadual Quintino Bocaiúva e Escola Municipal Professora Palmira Barbosa em Santa Cruz (RN). Caderno Virtual de Turismo, 12(3).

Souza, P. H. G. F., \& Medeiros, M. (2017). The concentration of income at the top in Brazil. Brasília: International Policy Centre for Inclusive Growth.

Sowman, M., Sunde, J., Raemaekers, S., Schultz, O., Halberg, N., \& Matose, F. (2014). Fishing for equality: Policy for poverty alleviation for South Africa's small-scale fisheries. Marine Policy, 46(1), 31-42. doi:10.1016/j.marpol.2013.12.005

Stecker, B. (2016). Tourismus. In K. Ott, J. Dierks, \& L. Voget-Kleschin (Eds.), Handbuch 
Umweltethik (pp. 297-304). Stuttgart/Weimar: J.B. Metzler

Stefanidaki, E., \& Lekakou, M. (2014). Cruise carrying capacity: A conceptual approach. Research in Transportation Business and Management, $\quad 13, \quad 43-52$. doi:10.1016/j.rtbm.2014.11.005

Strazza, C., Del Borghi, A., Gallo, M., Manariti, R., \& Missanelli, E. (2015). Investigation of green practices for paper use reduction onboard a cruise ship-a life cycle approach. International Journal of Life Cycle Assessment, 20(7), 982-993. doi:10.1007/s11367-015-0900-0

Strazza, C., Del Borghi, A., Magrassi, F., \& Gallo, M. (2016). Using environmental product declaration as source of data for life cycle assessment: a case study. Journal of Cleaner Production, 112, 333-342. doi:10.1016/j.jclepro.2015.07.058

Strazza, C., Magrassi, F., Gallo, M., \& Del Borghi, A. (2015). Life Cycle Assessment from food to food: A case study of circular economy from cruise ships to aquaculture. Sustainable Production and Consumption, 2, 40-51. doi:10.1016/j.spc.2015.06.004

Suntikul, W., \& Dorji, U. (2016). Tourism Development: The Challenges of Achieving Sustainable Livelihoods in Bhutan's Remote Reaches. International Journal of Tourism Research, 18(5), 447-457. doi:10.1002/jtr.2062

Sutton, P. (2004). A Perspective on Environmental Sustainability. A Paper for the Victorian Commissioner Environmental Sustainability. Strategy of Green Innovations, 27.

Tarlow, P. E. (2012). A segurança nos cruzeiros turísticos. In Abordagem Multidisciplinar dos Cruzeiros Turísticos (pp. 107-133). Leiria: Textiverso.

Tiago, T., Faria, S. D., Cogumbreiro, J. L., Couto, J. P., \& Tiago, F. (2016). Different shades of green on small islands. Island Studies Journal, 11(2),
601-618.

Tribou, M., \& Swain, G. (2015). Grooming using rotating brushes as a proactive method to control ship hull fouling. Biofouling, 31(4), 309-319. doi:10.1080/08927014.2015.1041021

UNEP. (2002). Global Environment Outlook (GEO 3). Past, present and future perspectives. United Nations Environment Programme. New York: United Nations Environment Program.

UNEP. (2005). Making tourism more sustainable: a guide for policy makers. WTO. United Nations Environment Program. New York: United Nations Environment Program.

United Nations. (1987). UN Documents: Gathering a body of global agreements. Our Common Future, Chapter 10: Managing The Commons. New York: United Nations Organization.

United Nations. (1992). United Nations Documents. Gathering a body of global agreements. Report of the World Commission on Environment and Development: Rio declaration on environment and development. New York: United Nations Organization.

United Nations. (1998). Kyoto protocol to the united nations climate change. New York: United Nations Organization.

United Nations. (2000). United Nations: Millenium declaration. New York: United Nations Organization.

United Nations. (2002). United Nations Documents. Gathering a body of global agreements. World Summit on Sustainable Development. Johannesburg Declaration on Sustainable Development. New York: United Nations Organization.

United Nations. (2005). Kyoto protocol. New York: United Nations Organization.

United Nations. (2007). Indicators of Sustainable Development: Guidelines and Methodologies 
(3rd ed.). New York: United Nations Organization. doi:10.1016/j.cirpj.2010.03.002

United Nations. (2009). Mainstreaming environmental sustainability. In country analysis and the UNDAF. A guidance note for United Nations country teams and implementing partners teams. New York: United Nations Organization.

United Nations. (2010). Sustainable Development: from Brundtland to Rio 2012. New York: United Nations Organization.

United Nations. (2012a). The future we want. Our Common Vision. New York: United Nations Organization.

United Nations. (2012b). United Nations Conference on Sustainable Development, Rio+20. New York: United Nations Organization.

United Nations. (2015a). Sustainable development goals. 17 goals to transform our world. Goal 14: Conserve and sustainably use oceans, seas and resources. New York: United Nations Organization.

United Nations. (2015b). Sustainable development goals. 17 goals to transform our world. Goal 17: Revitalize the global partnership for sustainable development. New York: United Nations Organization.

United Nations. (2015c). Transforming our world: the 2030 Agenda for Sustainable Development. UN General Assembley 70 session (Vol. 16301). New York: United Nations Organization. doi:/10.1007/s13398-014-0173-7.2

United Nations. (2016a). Sustainable development goals: 17 goals to transform the world. New York: United Nations Organization.

United Nations. (2016b). Sustainable development goals. 17 goals to transform our world. New York: United Nations Organization. United Nations. (2016c). Sustainable Development Goals Fund (SDGF): From MDGs to
SDGs. New York: United Nations Organization.

United Nations. (2016d). UNEP. United Nations Environment Programme. New York: United Nations Organization.

UNWTO. (2015). Sustainable Development of Tourism. Retrieved January 18, 2018, from http://sdt.unwto.org/content/about-us-5

UNWTO. (2016). Sustainable Cruise Tourism Development Strategies: Tackling the Challenges in Itinerary Design in South-East Asia. Madrid: World Tourism Organization.

Veal, A. J. (2011). Metodologia de pesquisa em lazer e turismo. São Paulo: Aleph.

Vezzani, M. A. (2008). Turismo rural e responsabilidade ambiental e ecológica no espaço rural brasileiro. Caderno Virtual de Turismo, 8(1).

Wackernagel, M., \& Rees, W. (1998). Our Ecological Footprint: Reducing Human Impact on the Earth. New Society Publishers.

Wakita, K., \& Oishi, T. (2016). Obligation to the Environment or Pursuit of Stylish Lifestyle: Which is More Important as a Determinant Factor for Intention of Green Consumer Behavior in the United States. In Conference on Environmental Information Science (pp. 85-90). Center for Environmental Information Science.

Walker, K., \& Moscardo, G. (2014). Encouraging sustainability beyond the tourist experience: ecotourism, interpretation and values. Journal of Sustainable Tourism, 22(8), 1175-1196. doi:10.1080/09669582.2014.918134

Walton, J. K. (2009). Prospects in tourism history: Evolution, state of play and future developments. Tourism Management, 30(6), 783-793. doi:10.1016/j.tourman.2009.05.010

Weeden, C., Lester, J.-A., \& Thyne, M. (2011). Cruise Tourism: Emerging Issues and Implications for a Maturing Industry. Journal of Hospitality 
and Tourism Management, 18(1), 26-29. doi:10.1375/jhtm.18.1.26

Weeratunge, N., Béné, C., Siriwardane, R., Charles, A., Johnson, D., Allison, E. H., ... Badjeck, M.-C. (2014). Small-scale fisheries through the wellbeing lens. Fish and Fisheries, 15(2), 255279. doi:10.1111/faf.12016

WEF. (2014). World Economic Forum. The Global Competitiveness Report 2014-2015. Genebra: WEF. doi:/ISBN-13: 978-92-95044-73-9

Whitfield, J., Dioko, L. A. N., \& Webber, D. E. (2014). Scoring environmental credentials: a review of UK conference and meetings venues using the GREENER VENUE framework. Journal of Sustainable Tourism, 22(2), 299-318. doi:10.1080/09669582.2013.809090

World Bank. (2016). World Development Indicators 2016. Washington, D.C.: World Bank. doi:/10.1596/978-1-4648-0683-4

Zhang, Y., Cole, S. T., \& Chancellor, C. H. (2013). Residents' Preferences for Involvement in Tourism Development and Influences from Individual Profiles. Tourism Planning \& Development, 10(3), 267-284. doi:10.1080/21568316.2012.747984
Informations on the authors

\section{Carlos Eduardo de Almeida Ramoa}

$\mathrm{PhD}$ in Tourism and Hotel Management; researcher in tourism studies at the University of Vale do Itajaí (Univali), Brazil. His research within the Research Group for Hotel Management and Tourism Services at the University of Vale do Itajaí (Univali), Brazil, focuses on strategy and sustainable tourism with specific interest in the environmental impacts of cruise ships, in marine and coastal areas.

E-mail: carlos.eduardo.ramoa@gmail.com Orcid: https://orcid.org/0000-0001-7053-1008

\section{Luiz Carlos da Silva Flores}

Professor of tourism studies in the Post-graduate Programme in Tourism and Hotel Management, Research Group for Hotel Management and Tourism Services at the University of Vale do Itajaí (Univali), Brazil. He received his PhD degree in Production Engineering from the Federal University of Santa Catarina (UFSC), Brazil. His research fields include strategies in tourism sustainable development and destination planning.

E-mail: luiz.flores@univali.br

Orcid: https://orcid.org/0000-0001-7747-4202

\section{Bernd Stecker}

Professor of leisure and tourism studies (B.A. and M.A.) at the Faculty of Social Sciences, City University of Applied Sciences, Hochschule Bremen, Germany. He received his PhD degree in Biology from the Institute for World Forestry, University of Hamburg, Germany. His research fields include sustainable development in leisure and tourism, biodiversity conservation and protected area tourism.

E-mail: bernd.stecker@hs-bremen.de

Orcid: https://orcid.org/0000-0002-6379-5475 